\title{
Effect of heat stress on carcass and meat quality of indigenous sheep of Bangladesh
}

\author{
MS Rana* ${ }^{1}$, MA Hashem², S Akhter ${ }^{2}$, M Habibullah², MH Islam², RC Biswas \\ ${ }^{1}$ Bangladesh Livestock Research Institute, Savar, Dhaka 1341; ${ }^{2}$ Department of Animal Science, Bangladesh \\ Agricultural University, Mymensingh 2202, Bangladesh.
}

\begin{abstract}
The research was conducted to study the effect of heat stress on carcass characteristics and meat quality in indigenous sheep. Nine sheep were divided into three groups which were almost similar in age, sex and weight. Three groups were divided as zero hour $\left(T_{0}\right)$, four hours $\left(T_{4}\right)$ and eight hours $\left(T_{8}\right)$ heat exposure to direct sunlight. During experimental period temperature-humidity index (THI) value was calculated as 27.09 which indicated $\mathrm{T}_{4}$ and $\mathrm{T}_{8}$ groups were subjected to heat stress condition for at least four hours and eight hours respectively every day. Slaughter weight, body length and heart girth had no significant difference among the treatment groups. Dry matter, ash and ether extract had no significant difference $(p>0.05)$ among the treatment groups but crude protein were increased with the increase of heat stress from $T_{0}$ to $T_{8}$ group $(p<0.05)$. Drip loss was increased $(p<0.05)$ in non-exposure group than treated groups but there is no significant result $(p>0.05)$ found in $\mathrm{pH}$ and cooking loss. Carcass weight and eye muscle area had no significant difference $(p>0.05)$ among the treatment groups but dressing percentage was decreased with the increase of time in heat treated groups $(p<0.01)$. Significant difference $(p<0.05)$ were found in weight of heart, kidney, lung + trachea and pluck between control and heat treated groups. The significant difference $(p>0.05)$ in empty gut was found in gut with content and gut fill in heat treated groups. It can be concluded that heat stress had significant changes on carcass characteristics and meat quality of indigenous sheep.
\end{abstract}

Key words: Heat stress, carcass, cooking loss, drip loss, dressing percentage, eye muscle area

Bangladesh Animal Husbandry Association. All rights reserved. Bang. J. Anim. Sci. 2014.43 (2): 147-153

\section{Introduction}

Sheep are important species of livestock in Bangladesh, providing meat and wool. Bangladesh possesses 2.97 million sheep at present (BER 2010), which was only 0.67 million during early 80's and current annual growth rate of national sheep herd is above $5 \%$, which is nearly 8 times than the growth rate of national cattle herd $(0.6 \%)$. Most of the sheep are indigenous, with few crossbreds (Bhuiyan et al. 2006) and are capable of bi-annual lambing and multiple births. Under traditional feeding systems, the sheep are raised on harvested or fallow lands, roads, and canal sides (Sultana and Hussain 2010) and also graze on aquatic weeds and grass in knee-deep water. With their small muzzles and split upper lips they can nibble tiny blades of vegetation, which cannot be eaten by bigger animals (Banerjee and Kato 1989).
High environmental temperature challenges the animal's ability to maintain energy, thermal, water, hormonal and mineral balance. High ambient temperature and humidity are the major constant on sheep productivity in tropical and subtropical areas. Sheep can withstand for hours an external temperature as high as $43^{\circ} \mathrm{C}$ during which both sweating and panting are important heat regulating mechanisms (Anderson 1989). In tropical and sub-tropical areas, indigenous sheep tend to breed throughout the year, although the sexual activity is restricted to a certain extent to the summer months (Kadim et al. 2007). This effect is aggravated when heat stress is accompanied by high ambient humidity. Exposure of sheep to elevated temperatures results in a decrease of body weight, average daily gain, growth rate and body total solids, which is reflected by impaired reproduction (Shelton 2000). The possible mechanisms involved in inducing the biological changes in heat-stressed 


\section{Heat stress on carcass quality in sheep}

sheep could have definite applications. The changes in the biological functions of sheep due to exposure to heat stress include the depression in feed intake and utilization, disturbance in the metabolism of water, protein, energy and mineral balances, enzymatic reactions, hormonal secretions and blood metabolites (Habeeb et al. 1992).

Climate change, particularly heat stress, could impact on meat safety as well as organoleptic quality. Global warming could affect microbial burdens on carcasses and meat, especially if the animals carry more enteric pathogens in their gut or on their body surface. The meat quality of sheep may be hampered by various physiological phenomena. First, extreme heat provokes an adrenergic stress response. Adrenaline stimulates peripheral vasodilatation and muscle glycogenolysis, and if exposure is protracted before slaughter it could lead to high $\mathrm{pH}$ and darker meat. However, in the case of sheep and broiler chickens, the acute heat stress that provokes sufficient adrenaline response to affect meat quality is very severe and is near the lethal limit (Lowe et al. 2002). Second, if an animal is exercised and develops hyperthermia before it is slaughtered, the combination of high temperature and anaerobic metabolism leads to an early and stronger rigor. There is a risk that the meat could be tougher through a heat-shortening effect, and this can occur in heat stressed animals that do not undergo forced exercise. Third, protracted high temperatures will lead to dehydration in water deprived animals and this can affect meat quality by making it darker in color through shrinkage of the myofibres, and because of its dryness it has less weight loss during cooking. Ambient temperature affected feed digestibility by altering the volume of the gastro-intestinal tract and the rate of passage of the digesta through the system. The decrease in rate of passage or the increase in the retention time of the digesta apparently increased the digestibility (Conrad 1985).

A major strategy to reduce the effect of heat stress on animals is to alter the environment through the use of sheds, fans or evaporative cooling (Bucklin et al. 1991). Such practices are not possible in semi-intensive systems as sheep are grazed in the open during most of the day. Moreover, Bangladesh is a sub-tropical country and sheep are generally reared by scavenging of naturally grown grasses. So they have to face heat stress during summer month. However, reports on the effects of chronic heat stress on physiological indices, carcass characteristics and meat quality in indigenous sheep are scarce and sporadic. There is urgent demand to address the effect of heat stress on physiological, biochemical and productive traits in sheep. Therefore, the present research work was undertaken to determine the effect of heat stress on carcass characteristics and meat quality in indigenous sheep.

\section{Materials and Methods}

Field trial was carried out in Goat, sheep and horse farm under the department of Animal Science. Laboratory analyses of the experimental samples were carried out in the laboratory of same department and also in the department of Physiology, Bangladesh Agricultural University, Mymensingh.

Nine indigenous sheep which were almost similar in age, sex and weight were selected for the experiment. Means of estimating the severity of heat stress was proposed using both ambient temperature and relative humidity, termed as the temperature humidity index (THI) (LPHSI 1990; Marai et al. 2007). When temperature is measured $\left({ }^{0} \mathrm{~F}\right)$, the equation to determine $\mathrm{THI}$ is as follows (LPHSI, 1990): $\mathrm{THI}=\mathrm{db}{ }^{0} \mathrm{~F}-\{(0.55-$ $\left.0.55 \mathrm{RH})\left(\mathrm{db}{ }^{0} \mathrm{~F}-58\right)\right\}$ where $\mathrm{db}{ }^{0} \mathrm{~F}$ is the dry bulb temperature in ${ }^{0} \mathrm{~F}$ and $\mathrm{RH}$ is the relative humidity $(\mathrm{RH} \%) / 100$, for sheep and goats. The obtained values indicate the following: values $<82=$ absence of heat stress; 82 to $<84=$ moderate heat stress; 84 to $<86=$ severe heat stress and over $86=$ extreme severe heat stress (LPHSI 1990). When the temperature is expressed in ${ }^{\circ} \mathrm{C}$, the equation of Marai et al. (2001) changes as follows: $\mathrm{THI}=\mathrm{db}{ }^{0} \mathrm{C}-\{(0.31$ - $\left.0.31 \mathrm{RH})\left(\mathrm{db}{ }^{0} \mathrm{C}-14.4\right)\right\}$ where $\mathrm{db}{ }^{0} \mathrm{C}$ is the dry bulb temperature $\left({ }^{\circ} \mathrm{C}\right)$ and $\mathrm{RH}$ is the relative humidity $(\mathrm{RH} \%) / 100$. The values obtained indicate the following: $<22.2=$ absence of heat stress; 22.2 to $<23.3=$ moderate heat stress: 23.3 to $<25.6=$ severe heat stress and 25.6 and more $=$ extreme severe heat stress (Marai et al. 2001). In the present study during experimental period average temperature was $27.84^{\circ} \mathrm{C}$ and average relative humidity was $81.90 \%$. Hence, 
THI value was 27.09 which indicate $T_{4}$ and $T_{8}$ groups were subjected to extreme severe heat stress condition for at least four hours and eight hours respectively every day.

Animals were housed in semi-intensive housing system in the Goat, sheep and horse farm of the department of Animal Science. All the sheep were kept in three groups (one group consists of three animals) in the room separated with fence. One group was assigned as control (average room temperature $23.6^{\circ} \mathrm{C}$ and relative humidity $65 \%$ i.e. zero hour heat exposure), and the rest two groups were served as heat stress such as 4 hours heat exposure from 10 am to $2 \mathrm{pm}$ and 8 hours heat exposure from 9 am to $5 \mathrm{pm}$. Roughage and concentrate feeds were supplied everyday at adequate amount. A large water trough was provided for each group to supply fresh water available ad libitum. The house was well ventilated and the space per animal was adequate. Cleaning and hygienic management was maintained regularly. The floor, stall, water trough, and feeder were cleaned every day. The feces were removed carefully from the house.

The heat stress period was 45 days, from 20 April 2011 to 5 June 2011. Before starting the collection of experimental data, all animals were subjected for acclimatization with the environment (e.g., daily routine activities) for about two months. All the animals were given 15 days for their psychological and physiological adjustment before starting the experiment for data collection.

The data about ambient temperature and relative humidity of these experimental days was collected from Meteorological Centre, Department of Irrigation and Water Management, Bangladesh Agricultural University, Mymensingh.

The initial body weight of each animal was recorded before morning feeding. The live weight gain was measured by subtracting the initial live weight from the final live weight. The rate of gain per day was calculated by dividing the total live weight gain by the number of total experimental days.

Sheep of each group were slaughtered to study the carcass and non-carcass parameters. Live weight, length of body and heart girth of each sheep were recorded prior to slaughter. Before slaughtering sheep were fasted for whole night. The "halal" method of slaughtering was followed. By this method sheep were bled by cutting throat and then slaughtered by severing the head at its articulation on the occipitoatlantal space. The conventional procedure of flaying was followed. At the time of slaughtering blood was collected in a pail. For the complete bleeding thorax of the sheep was pressed sufficiently. The weight of blood was recorded. Slaughtered sheep were hoisted by the hocks. The head was removed and weighed. The weight, length and width of skin were recrded. The entire digestive tract was removed and weighed. Again after removing gut fill, the empty gut was weighed and recorded. Heart, Spleen, Liver, Kidney, Lung+Trachea, Feet and Pluck were removed and weighed separately. Warm carcass weight was recorded immediately after completing dressing and evisceration.

Dressing percentage of the slaughtered animal was estimated using the following formula :

Dressing percentage $(\%)=$

$$
\frac{\text { Weight of the chilled carcass weight }}{\text { Live weight during slaughtering }} \times 100
$$

For measuring Eye Muscle Area (EMA) the hot carcass was split between $13^{\text {th }}$ and $14^{\text {th }}$ ribs. From the cross section the area was traced five times onto an acetate paper. Then from the weight-area relationship of the acetate paper the average area of each single 'eye' was estimated (Rahman, 2007). To estimate Eye Muscle Area (EMA) the following formula was followed :

$\operatorname{EMA}\left(\mathrm{cm}^{2}\right)=$

Weight of acetate paper for total eye muscle area

Weight of acetate paper for one $\mathrm{cm}^{2}$

Meat samples for chemical analyses i.e. proximate composition and for determination of $\mathrm{pH}$, drip loss and cooking loss were taken from same region of each slaughtered sheep. Twenty gram of meat sample for proximate composition, 5 gram of meat sample for $\mathrm{pH}, 60 \mathrm{~g}$ for drip loss and 60 gram of meat sample for cooking loss determination were taken from thigh region of each animal. All the samples were weighed 


\section{Heat stress on carcass quality in sheep}

carefully and packed seperately after labeling.

Proximate composition such as dry matter (DM), ether extract $(E E)$, crude protein $(C P)$ and ash were carried out according to the methods (AOAC 2005). All determinations were done in triplicate and the mean value was reported. The $\mathrm{pH}$ value of meat sample was measured using a $\mathrm{pH}$-meter from meat homogenate. The homogenate was prepared by blending $2 \mathrm{~g}$ of meat with $10 \mathrm{ml}$ distilled water.

From each sample, a standardized muscle cylinder (weighing about $60 \mathrm{gm}$ ) was suspended in an inflated plastic box $\left(4^{\circ} \mathrm{C}\right)$ for 24 hours. This work was done within 48 hours of postmortem. The percentage of drip loss was measured as described by Joo et al. (1995). The drip loss was estimated by using the following formula:

Drip loss $(\%)=$

Weight of sample - Weight of dry sample after $24 \mathrm{hrs}$ Weight of meat sample

Meat samples weighing about $60 \mathrm{gm}$ were boiled to an internal temperature of hot water bath at $90^{\circ} \mathrm{C}$ for 30 minutes, surface dried and weighed. Cooking loss was determined by expressing cooked sample weight (B) as a percentage of precooked sample weight (A) following the procedure of Yang et al. (2006).

Cooking loss $(\%)=$

$\frac{\text { Weight of precooked sample }- \text { Weight of cooked sample }}{\text { Weight of precooked sample }} \times 100$

The data in this experiment were analyzed statistically using the analysis of variance technique in a computer using SAS statistical computer package programmed in accordance with the principle of Completely Randomized Design (CRD). Duncan's Multiple Range Test was done to compare variations between treatments where ANOVA showed significant differences between means at a $5 \%$ level of significance.

\section{Results and Discussion}

Table 1 shows initial live weight, slaughter weight, body length and heart girth in nonexposure, 4 hours and 8 hours of heat exposure to the sheep. There was no significant difference $(p>0.05)$ among the groups for effect of heat stress on initial weight, slaughter weight, body length and heart girth of the sheep. Moniruzzaman et al. (2000) stated that body length and hearth girth varied significantly $(p<0.05)$ in different feeding systems.

Table 1. Effect of heat stress on pre-slaughter parameters

\begin{tabular}{lcccc}
\hline Parameter & $\mathrm{T}_{0}$ & $\mathrm{~T}_{4}$ & $\mathrm{~T}_{8}$ & Sig. level \\
\hline $\begin{array}{l}\text { Initial } \\
\text { weight (kg) }\end{array}$ & $9.83 \pm 1.30$ & $10.33 \pm 1.20$ & $9.53 \pm 0.23$ & $\mathrm{NS}$ \\
\hline $\begin{array}{l}\text { Slaughter } \\
\text { weight (kg) }\end{array}$ & $8.96 \pm 0.83$ & $11.33 \pm 0.92$ & $9.33 \pm 0.33$ & $\mathrm{NS}$ \\
\hline $\begin{array}{l}\text { Body } \\
\text { length (cm) }\end{array}$ & $45 \pm 1.45$ & $46.00 \pm 2.30$ & $43.33 \pm 1.45$ & $\mathrm{NS}$ \\
\hline $\begin{array}{l}\text { Heart girth } \\
(\mathrm{cm})\end{array}$ & $53.66 \pm 3.52$ & $58.33 \pm 2.91$ & $53.33 \pm 1.20$ & $\mathrm{NS}$ \\
\hline
\end{tabular}

NS, non significant, $T_{0}$, zero hour heat exposure group; $T_{4}$, four hour heat exposure group; $T_{8}$, eight hour heat exposure group

Table 2 shows dry matter, crude protein, ash, ether extract in non-exposure 4 hours and 8 hours of heat exposure to the sheep. There was no significant difference ( $p>0.05)$ among the groups for effect of heat stress on dry matter, ash and ether extract of the sheep. In this study crude protein was significantly higher $(p<0.05)$ in non-exposure group than 8 hour group but there is no significant difference $(p>0.05)$ between non-exposure and 4 hour exposure groups.

Table 2. Effect of heat stress on proximate components of meat

\begin{tabular}{lcccc}
\hline Parameter & $\mathrm{T}_{0}$ & $\mathrm{~T}_{4}$ & $\mathrm{~T}_{8}$ & Sig. level \\
\hline $\mathrm{DM}(\%)$ & $21.92 \pm 0.54$ & $21.86 \pm 0.77$ & $21.53 \pm 1.08$ & $\mathrm{NS}$ \\
\hline $\mathrm{CP}(\%)$ & $21.92^{\mathrm{a}} \pm 0.42$ & $20.57 \mathrm{ab} \pm 0.08$ & $18.577^{\mathrm{b}} \pm 1.07$ & ${ }^{*}$ \\
\hline Ash (\%) & $2.02 \pm 0.09$ & $1.98 \pm 0.04$ & $2.06 \pm 0.09$ & $\mathrm{NS}$ \\
\hline $\mathrm{EE}(\%)$ & $2.30 \pm 1.22$ & $2.60 \pm 0.18$ & $2.90 \pm 0.15$ & $\mathrm{NS}$ \\
\hline
\end{tabular}

Means with different superscript in the same row differed significantly $(*, \quad p<0.05) ; \quad N S$, non significant; $T_{0}$, zero hour heat exposure group; $T_{4}$, four hour heat exposure group; $T_{8}$, eight hour heat exposure group

There was a significant $(p<0.01)$ variation on percentage of ether extract due to feeding system (Moniruzzaman et al. 2000). Sen et al. (2001) observed $21.02 \% \mathrm{CP}$ in the yearling sheep under stall fed conditions in semiarid environment which is in close agreement with the 
findings of this study. Cloete et al. (2012) measured $1.07 \%, 1.06 \%, 1.21 \%$ and $1.10 \%$ ash in Merino, Dohne Merino, SAMM and Dormer sheep respectively and $2.19 \%, 3.03 \%, 3.97 \%$ and $3.19 \%$ ether extract in those four breeds respectively.

Table 3 shows the effect of heat stress on $\mathrm{pH}$, drip loss, cooking loss, carcass weight, dressing percentage and eye muscle area in sheep. There was no significant effect of heat stress on $\mathrm{pH}$ and cooking loss of sheep. Drip loss significantly higher $(p<0.05)$ in non-exposed group than 8 hour exposure group but there was no significant difference $(p>0.05)$ between non-exposure and 4 hour exposure groups and between 4 hour and 8 hour exposure groups. Heat stress did not cause significant change $(p>0.05)$ on carcass weight and eye muscle area of the sheep. However, in this study dressing percentage was higher $(p<0.01)$ in non-exposure group than exposure groups and 4 hour exposure group

Table 3. Effect of heat stress on meat quality and carcass parameters

\begin{tabular}{lcccc}
\hline Parameter & $\mathrm{T}_{0}$ & $\mathrm{~T}_{4}$ & $\mathrm{~T}_{8}$ & Sig. level \\
\hline $\mathrm{pH}$ & $5.83 \pm 0.02$ & $5.73 \pm 0.06$ & $5.84 \pm 0.15$ & $\mathrm{NS}$ \\
$\mathrm{DL}(\%)$ & $18.54 \mathrm{a} \pm 0.86$ & $16.94^{\mathrm{a} b} \pm 1.36$ & $14.62^{\mathrm{b}} \pm 0.57$ & $*$ \\
$\mathrm{CL}(\%)$ & $41.46 \pm 1.12$ & $42.51 \pm 3.85$ & $43.69 \pm 2.29$ & $\mathrm{NS}$ \\
$\mathrm{CW}(\mathrm{kg})$ & $4.07 \pm 0.41$ & $4.57 \pm 0.38$ & $3.50 \pm 0.15$ & $\mathrm{NS}$ \\
$\mathrm{DP}(\%)$ & $45.31^{\mathrm{a}} \pm 0.49$ & $40.28^{\mathrm{b}} \pm 0.28$ & $37.48^{\mathrm{c}} \pm 0.42$ & $* *$ \\
EMA $\left(\mathrm{cm}^{2}\right)$ & $6.97 \pm 1.84$ & $7.76 \pm 1.88$ & $6.21 \pm 1.19$ & $\mathrm{NS}$ \\
\hline
\end{tabular}

$\mathrm{DL}$, drip loss; $\mathrm{CL}$, cooking loss; CW, carcass weight; DP, dressing percentage; EMA, eye muscle area; means with different superscript in the same row differed significantly $(*, \quad \mathrm{p}<0.05 ; * *, \mathrm{p}<0.01) ; \mathrm{NS}$, non significant; $T_{0}$, zero hour heat exposure group; $T_{4}$, four hour heat exposure group; $\mathrm{T}_{8}$, eight hour heat exposure group

Sen et al. (2001) found $\mathrm{pH}$ value 5.93 in the yearling sheep under stall fed conditions semiarid environment where drip loss and cooking loss were $3.86 \%$ and $20.74 \%$ respectively. Kadim et al. (2006) observed higher $\mathrm{pH}$ value (5.98) and cooking loss $(20.8 \%)$ after transportation stress at high ambient temperatures of three breeds of Omani goats. Kadim et al. (2007) recorded higher value of $\mathrm{pH}$ in hot season (5.77) than in cold season (5.60) in case of Somali and Merino Sheep. Cloete et al. (2012) measured $32.0 \%$ $29.6 \%, 30.1 \%$ and $29.3 \%$ cooking loss in Merino, Dohne Merino, SAMM and Dormer sheep respectively. Sen et al. (2001) found that the yearling sheep had higher $(p<0.05)$ slaughter weight $(28.54 \mathrm{~kg})$, empty live weight $(26.65 \mathrm{~kg})$, hot carcass weight $(14.88 \mathrm{~kg})$ and dressing percentage $(52.14 \%)$ under semiarid conditions. Yousefi et al. (2012) determined $42.61 \%-44.93 \%$ dressing percentage in traditional fat-tailed and tailed I ranian sheep breeds. Singh et al. (1983) and Rahman (2007) reported that rib eye area was highly associated with carcass weight as well as dressing percentage.

Table 4 shows the effect of heat exposure on heart, spleen, liver, kidney, lung+trachea, head, feet, pluck in sheep. There was no significant difference $(p>0.05)$ on spleen, liver, head, feet, and blood of the sheep. In this study, heart and lung+trachea were significantly higher $(p<0.05)$ in non-exposure group than 8 hour exposure but there was no significant difference between nonexposure and 4 hour exposure groups and between 4 hour exposure and 8 hour exposure groups. On the other hand, kidney and pluck were significantly higher $(p<0.05)$ in 4 hour exposure group than 8 hour exposure but there was no significant difference $(p>0.05)$ between non-exposure and 4 hour exposure groups and between non-exposure and 8 hour exposure groups.

Table 4. Effect of heat stress on by-product parameters

\begin{tabular}{lccc}
\hline Parameter & $\mathrm{T}_{0}$ & $\mathrm{~T}_{4}$ & $\mathrm{~T}_{8}$ \\
\hline Heart $(\mathrm{g})$ & $45.00^{\mathrm{a}} \pm 7.64$ & $36.67^{\mathrm{a}} \pm 8.82$ & $15.67^{\mathrm{b}} \pm 2.33$ \\
\hline Spleen $(\mathrm{g})$ & $20.00 \pm 5.77$ & $27.33 \pm 7.05$ & $16.67 \pm 6.67$ \\
\hline Liver $(\mathrm{g})$ & $121.67 \pm 19.65$ & $181.00 \pm 38.53$ & $146.67 \pm 24.04$ \\
\hline Kidney $(\mathrm{g})$ & $16.67^{\mathrm{a}} \pm 3.33$ & $26.67 \mathrm{a} \pm 6.00$ & $11.67 \mathrm{~b} \pm 1.67$ \\
\hline Lung+ & $110.00^{\mathrm{a}} \pm 11.55$ & $98.33^{\mathrm{ab} \pm 11.67}$ & $70.00^{\mathrm{b}} \pm 5.77$ \\
Trachea $(\mathrm{g})$ & & & \\
\hline Head $(\mathrm{g})$ & $656.67 \pm 124.14$ & $856.67 \pm 118.51$ & $550.00 \pm 51.32$ \\
\hline Feet $(\mathrm{g})$ & $160.00 \pm 20.82$ & $180.00 \pm 30.55$ & $149.00 \pm 21.08$ \\
\hline Pluck $(\mathrm{g})$ & $406.67 \mathrm{a} \pm 17.64$ & $516.67 \mathrm{a} \pm 72.65$ & $263.33^{\mathrm{b}} \pm 31.79$ \\
\hline Blood $(\mathrm{g})$ & $285.00 \pm 51.07$ & $350.00 \pm 37.86$ & $266.67 \pm 31.79$ \\
\hline
\end{tabular}

Means with different superscript in the same row differed significantly $(p<0.05) ; T_{0}$, zero hour heat exposure group; $T_{4}$, four hour heat exposure group; $T_{8}$, eight hour heat exposure group

Moniruzzaman et al. (2000) found the similar result, which in consistent with this study. They observed higher value of weight of head, lung, feet and blood in grazing and restricted grazing group (heat stress group) which had a 
contribution in lowering dressing percentage. Weight of liver, kidney and pluck were higher in grazing group which is also consistent with this study. Weight of heart and spleen were higher in stall fed goat, which is in line with this study.

Table 5 shows the effect of heat stress on weight of skins, length of skin, width of skin, gut with content, empty gut and gut fill in sheep. There was no significant difference $(p>0.05)$ on weight of skin, length of skin and width of skin among the group in sheep. It is observed from the Table that there was no significant difference $(p>0.05)$ among the groups due to heat stress on gut with content and gut fill of the sheep. However, empty gut was found significantly higher $(p<0.05)$ in 4 hour exposure group than non-exposure and 8 hour groups but there was no significant difference $(p>0.05)$ between non-exposure and 8 hour exposure group.

Table 5. Effect of heat stress on skin and gut parameters

\begin{tabular}{lccc}
\hline Parameter & $\mathrm{T}_{0}$ & $\mathrm{~T}_{4}$ & $\mathrm{~T}_{8}$ \\
\hline Weight of skin $(\mathrm{g})$ & $753.3 \pm 89.50$ & $950.0 \pm 273.37$ & $703.3 \pm 73.56$ \\
\hline Length of skin $(\mathrm{cm})$ & $70.00 \pm 4.58$ & $79.67 \pm 7.21$ & $66.67 \pm 3.67$ \\
\hline Width of skin $(\mathrm{cm})$ & $62.67 \pm 2.40$ & $64.00 \pm 4.16$ & $56.00 \pm 5.29$ \\
\hline Gut with content $(\mathrm{kg})$ & $3.63 \pm 0.56$ & $3.0 \pm 0.03$ & $3.03 \pm 0.20$ \\
\hline Empty gut $(\mathrm{kg})$ & $1.28^{\mathrm{b}} \pm 0.13$ & $1.69 \mathrm{a} \pm 0.04$ & $1.16^{\mathrm{b}} \pm 0.09$ \\
\hline Gut fill $(\mathrm{kg})$ & $2.35 \pm 0.43$ & $1.40 \pm 0.06$ & $1.87 \pm 0.13$ \\
\hline
\end{tabular}

Means with different superscript in the same row differed significantly $(p<0.05) ; T_{0}$, zero hour heat exposure group; $T_{4}$, four hour heat exposure group; $T_{8}$, eight hour heat exposure group

Moniruzzaman et al. (2000) reported that weight of skin, length of skin, weight of skin were significantly higher $(p<0.05)$ in stall fed group than tethering group (heat stress group). They found that gut with content, empty gut and gut fill were higher in tethering group than stall fed group (non-exposure group) where empty gut was significantly higher in tethering group (heat stress group).

\section{Conclusion}

It can be concluded from the above findings that maximum carcass characteristics and meat quality of indigenous sheep is highly affected by heat stress. So, attempt should be paid to minimize the heat stress of sheep for their optimum performance.

\section{References}

Anderson BE (1989). Temperature Regulation and Environmental Physiology. In: Swenson, M.J. (Ed.), Dukes' Physiology of Domestic Animals, $10^{\text {th }}$ edition, Cornell University Press, Ithaca, NY. P. 719-727.

AOAC (Association of Official Analytical Chemists) (2005). Official Methods of Analysis, Association of Official Analytical Chemists. $13^{\text {th }}$ Ed., Washington, DC. P. 957.

Banerjee T, Kato M (1989). Effect of wheat bran supplement to rice straw diet on the ruminating behaviour in sheep. Bulletin of the Faculty of Agriculture, Shimane University, 13: 21-26.

BER (Bangladesh Economic Review) (2010). Economic Review, Statistics Division, Ministry of Planning, Government of the People's Republic of Bangladesh.

Bhuiyan M, Ismail E, Abdel-Latif H, Hassan GA, Salem MH (2006). Water metabolism and requirements of sheep as affected by breed and season. World Review on Animal Production, 30: 95-105.

Bucklin RA, Turner LW, Beede DK, Bray DR, Hemken RW (1991). Methods to relieve heat stress for dairy cows in hot, humid climates. Applied Engineering and Agriculture, 7: 241-246.

Cloete JJE, Hoffman LC, Cloete SWP (2012). A comparison between slaughter traits and meat quality of various sheep breeds: Wool, dual-purpose and mutton. Journal of Meat Science, 91: 318-324.

Conrad JH (1985). Feeding of farm animals in hot and cold environments. In: Yousef MK (Ed.), Stress Physiology in Livestock. CRC Press, Inc., Boca Raton, Florida, USA, Place, Corvallis, OR 97330, USA.

DLS (Department of Livestock Servece) (2012). Ministry of Fisheries and livestock, Government of the People's Republic of Bangladesh.

Habeeb AA, Marai IFM, Kamal TH (1992). Heat stress. In: Philips, C., Piggens, D. (Eds.), Farm Animals and the Environment. C.A.B. International. P. 27-47.

J oo ST, Kim BC, Kim CJ (1995). The relationship between color and water-holding capacity in post-rigor porcine longissimus muscle. Journal of Muscle Foods, 6: 200-226. 
Rana et al. (2014) Bang. J. Anim. Sci. 43 (2): 147- 153

Kadim IT, Mahgoub O, Al-Kindi A, Al-Marzooqi W, Al-Saqri NM (2006). Effects of transportation at high ambient temperatures on physiological responses, carcass and meat quality characteristics of three breeds of Omani goats. Journal of Meat Science, 73: 626-634.

Kadim IT, Mahgoub O, Al-Marzooqi W, Al-Ajmi DS, Al-Maqbali RS, Al-Lawati SM (2007). The influence of seasonal temperatures on meat quality characteristics of hot-boned, m. psoas major and minor, from goats and sheep. Journal of Meat Science, 80: 210215.

Lowe TE, Gregory NG, Fisher AD, Payne SR (2002). The effects of temperature elevation and water deprivation on lamb physiology, welfare, and meat quality. Australian J ournal of Agricultural Research, 53: 707-714.

LPHSI (1990). Livestock and Poultry Heat Stress Indices Agriculture Engineering Technology Guide. Clemson University, Clemson, SC 29634, USA.

Marai IFM, Ayyat MS, Abd El-Monem UM (2001). Growth performance and reproductive traits at first parity of New Zealand White female rabbits as affected by heat stress and its alleviation, under Egyptian conditions. Journal of Tropical Animal Health and Production, 33: 457-462.

Marai IFM, Bahgat LB, Shalaby TH, Abdel-Hafez MA (2007). Fattening performance, some behavioral traits and physiological reactions of male lambs fed concentrates mixture alone with or without natural clay, under hot summer of Egypt. Journal of Annals of Arid Zone, 39: 449-460.

Moniruzzaman M, Hashem MA, Akhter S, Hossain MM (2000). Effect of different feeding systems on carcass and non-carcass parameters of Black Bengal goat. AsianAustralasian Journal of Animal Sciences, 15: 61-65.

Rahman MF (2007). Estimation of relationship between hot carcass weight and eye muscle area which affects on meat production of Black Bengal goat. Pakistan J ournal of Nutrition, 6: 33-34.

Sen AR, Santra A, Karim SA (2001). Carcass yield, composition and meat quality attributes of sheep and goat under semiarid conditions. Journal of Meat Science, 66: 757-763.

Shelton M (2000). Reproductive performance of sheep exposed to hot environments. In: Malik, RC, Razzaque, MA, Al-Nasser, AY (Eds.), Sheep Production in Hot and Arid Zones. Published by the Kuwait Institute for Scientific Research. P. 155-162.

Singh CPS, Singh DK, Singh R, Nath S, Mishra HR (1983). Some Carcass Characters of Black Bengal and Crossbred goats. Indian J ournal of Animal Science, 53: 560-561.

Sultana HA, Hussain F (2010). Intake and utilization of nutrients in sheep feeding different level of forage under heat stress. J ournal of Animal Science, 38: 877-886.

Yang HS, Moon SS, Jeong JY, Choi SG, J oo ST, Park GB (2006). Effect of sodium bicarbonate injection in pre-rigor porcine M. Longissimus lumborum on pork quality. Asian-Australasian Journal of Animal Science, 19: 898-904.

Yousefi AR, Kohram H, Shahneh AZ, Nik-khah A, Campbell AW (2012). Comparison of the meat quality and fatty acid composition of traditional fat-tailed (Chall) and tailed (Zel) Iranian sheep breeds. Journal of Meat Science, 92: 417-422. 